\title{
"We Never Get Stuck:" A Collaborative Analysis of Change and Coastal Community Subsistence Practices in the Northern Bering and Chukchi Seas, Alaska
}

\author{
Henry P. Huntington, ${ }^{1}$ Julie Raymond-Yakoubian, ${ }^{2}$ George Noongwook, ${ }^{3}$ Noah Naylor, ${ }^{4}$ Cyrus Harris, ${ }^{5}$ \\ Qaiyaan Harcharek ${ }^{6}$ and Billy Adams ${ }^{7}$
}

(Received 30 October 2019; accepted in revised form 28 October 2020)

\begin{abstract}
The Indigenous communities of the northern Bering Sea and Chukchi Sea are experiencing extensive social, economic, and technological change. The region's marine ecosystem is also characterized by a high degree of variability and by rapid change. Residents of eight coastal communities from Savoonga to Utqiagivik were involved in the Chukchi Coastal Communities Project, which used the results of a literature review together with the experiences of the community participants to co-analyze what is known about societal and environmental change in the region and what the communities' experiences have been in responding to those changes. Some of the observed changes are transient in duration and effect, such as the passage of an individual ship, whereas others, such as the creation of the Red Dog Mine Port Site, persist and may force coastal residents to make lasting changes in their activities. Some responses can use existing knowledge (e.g., hunting bowhead whales in fall as well as spring), whereas others may require learning and experimentation (e.g., harvesting new species such as the Hanasaki crab). Our findings show that the results of a change are more important than the source of the change. They also emphasize the continuing importance of traditional values and practices as well as attitudes conducive to persistence and innovation. Indigenous leadership is an essential component of continued resilience as the ecosystem continues to change. The resilient characteristics of coastal communities and their ability to determine their own responses to change need greater attention to match the research effort directed at understanding the ecosystem.
\end{abstract}

Key words: Chukchi Sea; Bering Sea; Iñupiaq; St. Lawrence Island Yupik; subsistence; response

RÉSUMÉ. Les collectivités autochtones du nord de la mer de Béring et de la mer des Tchouktches font face à d'importants changements sur les plans social, économique et technologique. L'écosystème marin de la région est également caractérisé par un grand degré de variabilité et de changement rapide. Les habitants de huit collectivités côtières, de Savoonga à Utqiagivik, ont participé au projet des collectivités côtières des Tchouktches. S'appuyant sur l'examen de documentation et sur l'expérience des participants des collectivités, les responsables de ce projet ont co-analysé les faits connus au sujet du changement social et environnemental dans la région de même que l'expérience des collectivités en matière de réponse à ces changements. La durée et l'effet des changements observés sont parfois transitoires, comme le passage d'un navire, tandis que d'autres, comme l'aménagement du site portuaire de la mine de Red Dog, perdurent et risquent de forcer les habitants de la côte à modifier leurs activités en permanence. Certaines des réponses peuvent s'appuyer sur des connaissances déjà acquises (comme le fait de chasser la baleine boréale à l'automne ainsi qu'au printemps), tandis que d'autres pourraient nécessiter de l'apprentissage et de l'expérimentation (comme la récolte d'une nouvelle espèce comme le crabe Hanasaki). Nos constatations démontrent que les résultats d'un changement sont plus importants que la source du changement. Elles mettent également l'accent sur l'importance continuelle des valeurs et des pratiques traditionnelles ainsi que sur les attitudes propices à la persistance et à l'innovation. Le leadership autochtone est une composante essentielle de la résilience continue alors que l'écosystème évolue sans cesse. Les caractéristiques de résilience des collectivités côtières et leur capacité à déterminer leurs propres réponses au changement doivent faire l'objet d'une plus grande attention afin d'être à la hauteur de l'effort de recherche visant à comprendre l'écosystème.

Mots clés : mer des Tchouktches; mer de Béring; Iñupiaq; Yupik de l'île St. Lawrence; subsistance; réponse

Traduit pour la revue Arctic par Nicole Giguère.

\footnotetext{
${ }^{1}$ Corresponding author: 23834 The Clearing Drive, Eagle River, Alaska 99577, USA; henryphuntington@gmail.com

${ }^{2}$ Kawerak Social Science Program, PO Box 924, Nome, Alaska 99762, USA

${ }^{3}$ Savoonga Whaling Captains Association, PO Box 81, Savoonga, Alaska 99769, USA

${ }^{4}$ Northwest Arctic Borough, PO Box 1110, Kotzebue, Alaska 99752, USA; current address: Kikiktagruk Inupiat Corporation, PO Box 1050, Kotzebue, Alaska 99752, USA

${ }^{5}$ Maniilaq Association, PO Box 256, Kotzebue, Alaska 99752, USA

${ }^{6}$ North Slope Borough, PO Box 69, Utqiagivik, Alaska 99723, USA

${ }^{7}$ North Slope Borough Department of Wildlife Management, PO Box 69, Utqiagivik, Alaska 99723, USA

(C) The Arctic Institute of North America
} 


\section{INTRODUCTION}

Subsistence activities, which include traditional hunting, fishing, and gathering practices, provide vital cultural, nutritional, economic, social, and spiritual benefits to Indigenous residents of the northern Bering Sea and Chukchi Sea coast of western and northern Alaska (ICCAlaska, 2015; Raymond-Yakoubian, 2019). In recent years, much attention has been given to the effects of climate change on subsistence and other aspects of Indigenous community life in Alaska and elsewhere (e.g., Fall et al., 2013; Gadamus, 2013; Pearce et al., 2015). At the same time, community members and researchers both recognize that subsistence practitioners have long dealt with considerable environmental variability on time scales from hours to decades (Kapsch et al., 2010; Huntington et al., 2013). In addition to environmental considerations, subsistence practices have been affected by social, economic, regulatory, technological, and other forms of change (Kersey, 2011; Moerlein and Carothers, 2012; RaymondYakoubian, 2013; Huntington and Eerkes-Medrano, 2017). These societal shifts have affected both the demand for subsistence foods and the ability to procure those foods (Fall et al., 2013). For example, modern hunting equipment facilitates access but requires money for its purchase, maintenance, and operation, which can limit participation for those with limited access to cash. While negative effects on subsistence get much attention and for good reason, the various changes communities have experienced have also had positive effects (e.g., Noongwook et al., 2007; Huntington et al., 2017a), in part due to the ability of communities to adjust where possible and to take advantage of opportunities.

That ability to adjust and to find and create opportunities is an essential attitude in an environment characterized by variability, as is the case for the northern Bering and Chukchi Sea marine ecosystem (e.g., Moore et al., 2018; Huntington et al., 2020). Weather and sea ice conditions can change within hours and can vary greatly from year to year. The harvest of marine mammals, seabirds, and fish in coastal communities also varies from year to year (e.g., Fall et al., 2013). If the Iñupiat and St. Lawrence Island Yupik of Alaska's western and northern coasts were unable to cope with that variability, their communities could not have persisted (e.g., Hovelsrud and Smit, 2010). This is not to say that such strategies are always effective. In both oral history and the archeological record, there is abundant evidence of the abandonment of settlements and shifts in subsistence patterns and technology (e.g., Mason and Gerlach, 1995). Nonetheless, the application of knowledge and skills to changing conditions, also described as adaptations to change, have been described in a number of papers. Thornton and Manasfi (2010), for example, define eight modes of adaptation, such as mobility and diversification. In addition, Walker and Salt (2012) describe societal characteristics or attitudes that promote adaptive responses, such as openness and diversity.
Huntington et al. (2017a) examine how communities are able to respond to change, autonomously or in collaboration with others outside the community. Amid current concerns about the effects of climate change on the Arctic and its residents (e.g., Brinkman et al., 2016), the question of how coastal residents respond to change is ever more pertinent, deserving of detailed attention at the community level.

Our study started from the premise that much has already been documented about Indigenous observations of, experiences with, and responses to variability and change in this region. Rather than engage in another effort to interview community residents, we elected to engage community-identified experts in a co-analysis of the existing information. This approach is part of a shift in the role of community participants from providers of information to interpreters of information, and part of a wider movement towards meaningful collaborations, Indigenous leadership in research, and the co-production of knowledge, a paradigm emphasizing the need to work together from start to finish in research projects (Lemos and Morehouse, 2005; Bartlett et al., 2012; Meadow et al., 2015; Whyte, 2017; David-Chavez and Gavin, 2018; Peltier, 2018; Kirby et al., 2019). The aim of the study and of this paper therefore is not to generate or report new observations and basic information, but to take a new look at what is already on record, to better understand the meanings and implications of that existing information from the perspective of Indigenous communities.

Our project had two questions in mind. First, do different types of change manifest themselves in different ways, for example in the timescale on which they operate, and do they have demonstrable effects on subsistence outcomes? Climate change and other modes of change such as the effects of industrialization or commercial fishing are often regarded as major influences on subsistence practices (e.g., Cochran et al., 2013; Brinkman et al., 2016). We seek evidence to support that oft-repeated assertion.

Second, what strategies are used by Iñupiaq and St. Lawrence Island Yupik residents of Alaska's northern Bering Sea and Chukchi Sea coasts? If the strategies being used are likely to be effective in light of continued change to the ecosystem, it will be important to support the use of those strategies. If the strategies are unlikely to continue to be effective, it will be important to recognize their shortcomings and for coastal communities to develop alternatives. We conclude by considering the context in which environmental change affects the region's communities and its implications for the future well-being of those communities.

The study area for this project extends from St. Lawrence Island in the northern Bering Sea to Utqiagivik at the edge of the Chukchi and Beaufort Seas (Fig. 1). There are over a dozen Alaska Native communities along the coast or close enough to the coast to use the marine environment for subsistence. Of these, we invited nine communities to join the project based on their connections to the sea, their participation in previous collaborative research efforts of 


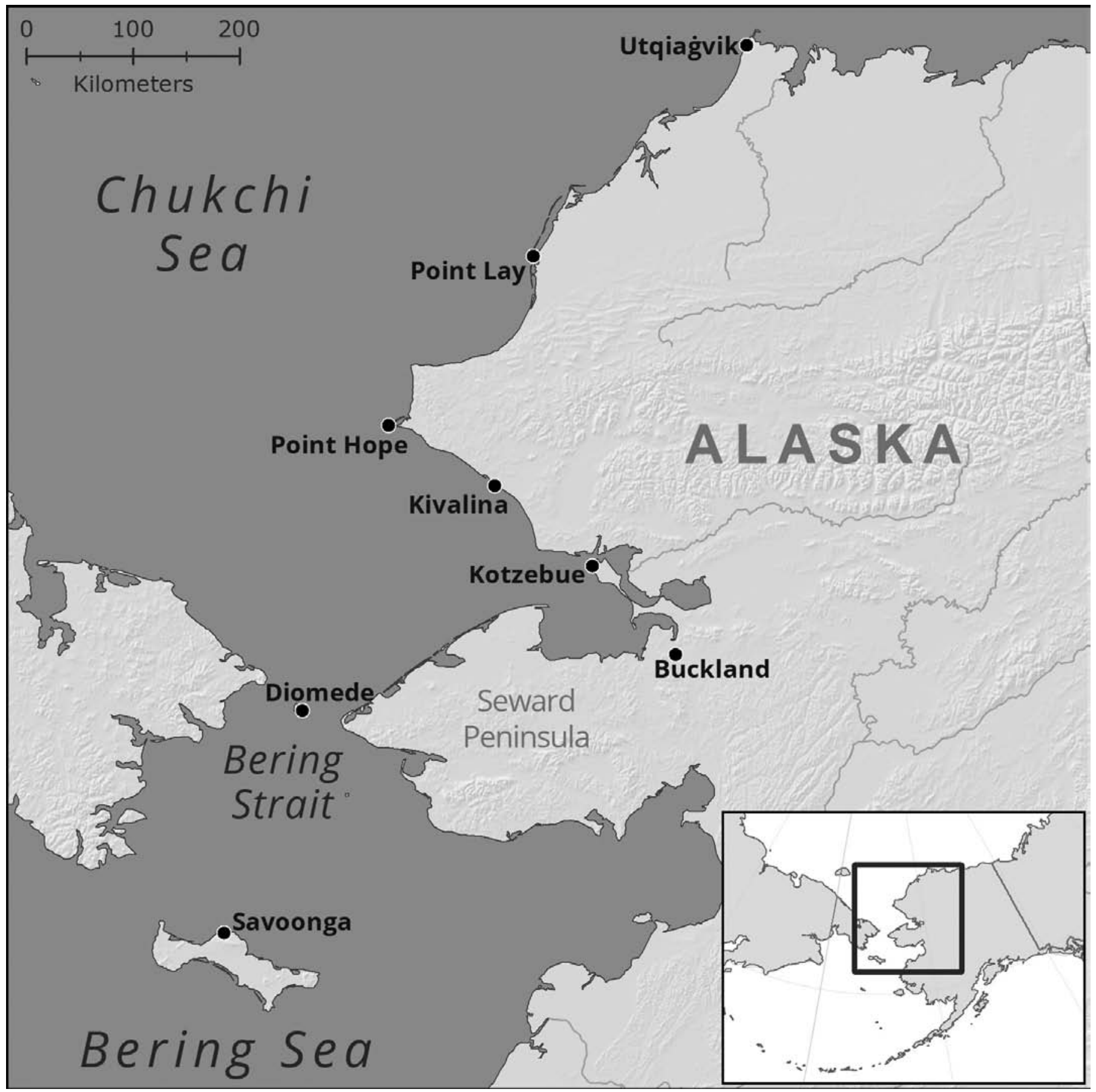

FIG. 1. Map of the region showing the communities with experts on the project team.

this type, and their willingness to take part. Eight were able to accept: Savoonga (2020 population est. 712; Alaska Department of Labor and Workforce Development, 2021), Diomede (84), Buckland (465), Kotzebue (3064), Kivalina (423), Point Hope (687), Point Lay (248), and Utqiagivik (4436; formerly known as Barrow). The participant chosen by the ninth community was unable to attend because of schedule conflicts and no substitute could be arranged. The communities are Iñupiaq and St. Lawrence Island Yupik, referred to collectively here as the "Chukchi coastal communities."

\section{METHODS}

The Chukchi Coastal Communities Project is part of the North Pacific Research Board's Arctic Integrated Ecosystem Research Program (Arctic IERP; http:// www.nprb.org/arctic-program/about-the-program/). The Arctic IERP includes several projects spanning physical oceanography to social science in an effort to consider the Chukchi Sea ecosystem and the implications of the environmental changes taking place in the region. The scope of the Arctic IERP was shaped in part by previous 
efforts to engage coastal communities in the planning and conduct of Arctic research (Grebmeier, 2014). The Chukchi Coastal Communities Project examines the ways environmental changes affect the Iñupiaq and St. Lawrence Island Yupik communities along the Chukchi Sea coast of Alaska and also seeks to make available their observations of change in order to contribute to the program's collective understanding of what is happening in the region's marine environment.

Recognizing that Alaska Native communities have been the subject of extensive research concerning subsistence and environmental change (among many other topics; see, e.g., Cochran et al., 2013 and references therein; Raymond-Yakoubian and Raymond-Yakoubian, 2017), the Chukchi Coastal Communities Project does not include primary research, such as interviews, in the communities. We instead conducted a literature review of publications relevant to Chukchi coastal communities and their role in the marine ecosystem. We found 248 publications, including articles in scientific journals, books, reports, and other materials. The review began with papers known to the project team and by reviewing the reference lists of the publications already in the collection. We expanded through Internet searches using key words such as "Bering, Chukchi, Bering Strait, North Slope, Northwest Arctic, subsistence, Indigenous, Alaska Native, hunting, climate change, adaptation, resilience," and other terms and combinations found in the works already in our collection. The bibliographic details of the publications and a short list of key points or topics for each one were compiled into a document archived in the Arctic IERP data collection. This material is summarized below and constitutes the starting point for our co-analysis discussions.

In parallel to the literature review, members of the eight participating communities along the coast were identified as experts and selected by the project leads in cooperation with tribal and community leaders to take part in meetings to review and co-analyze what is known about societal and environmental change in the region and what these data tell us concerning the communities' experiences and well-being. By "co-analysis," we mean an effort to work together, not simply for academically trained researchers to ask questions of community experts and take notes, but for all involved to discuss observations and implications of changes, effects, and responses, based on each person's experiences and understanding.

The meeting discussions were organized around the questions mentioned in the Introduction. In March 2017, the project team met in Anchorage, Alaska, with 12 residents of the coastal communities (including two of the project leads) and two project leaders who live in the greater Anchorage area. In March 2018, the project team met again in Anchorage, this time with 11 residents of coastal communities (including two project leads and one project staff person) and the two project leaders from the Anchorage area. In both years, notes were taken of the discussions, circulated to participants for review and correction, and archived as part of the Arctic IERP data collection.

The authors of this paper include the project leads as well as community experts who were interested in contributing to the paper, beyond the meeting discussions. The overall project lead (H.P. Huntington) is a non-Indigenous scholar living near Anchorage, Alaska. Project co-leads include a non-Indigenous scholar living in the Anchorage area (J. Raymond-Yakoubian) and working for Kawerak, Inc., a regional non-profit organization based in Nome; an Iñupiaq from Kotzebue who at the time of the research was the planning and science director for the Northwest Arctic Borough (N. Naylor); and an Iñupiaq from Utqiagivik who at the time of the research was a subsistence research specialist with the North Slope Borough Department of Wildlife Management (Q. Harcharek). The three remaining co-authors are a St. Lawrence Island Yupik whaling captain and local leader from Savoonga (G. Noongwook), an Iñpiaq provider of social services in Kotzebue who grew up on the land away from the community (C. Harris), and an Iñuiaq employee of the North Slope Borough Department of Wildlife Management from Utqiagivik (B. Adams). All five of the Indigenous co-authors are active and experienced subsistence practitioners with additional extensive experience as members of formal scientific research efforts.

\section{CAUSES, EFFECTS, AND RESPONSES TO CHANGE}

The literature review provided numerous examples of changes that have occurred in Chukchi coastal communities and their surroundings over the past years and decades, the resulting effects of these changes on subsistence practices and outcomes, and the range of ways that individuals and communities have responded. These documented examples were complemented by observations of project team members during the co-analysis meetings. The list is not exhaustive. Instead, we have selected examples that community experts identified as representative of common experiences and trends and that illustrate a range of factors driving those changes.

We found dozens of examples of effects on subsistence practices. Fewer studies documented clear changes in outcomes, such as reduced (or increased) harvest levels. The causes of effects on subsistence can be divided first into societal and environmental categories and then further into subcategories. Environmental changes include changing weather, changing sea ice, changing abundance or distribution of harvested species, and the availability of new species to harvest. Societal changes include industrial activity such as shipping or offshore oil and gas activity, technological change, social or cultural change, economic change, and regulatory change. We considered both the short-term effects, lasting a season or less, and longterm effects, lasting for years or decades. A summary of examples of changes and effects is presented in Table 1. 
TABLE 1. Examples of changes experienced by Chukchi coastal communities and their short- and long-term effects on subsistence. These examples were documented in the literature included in our project bibliography and complemented by additional observations shared in our project meetings.

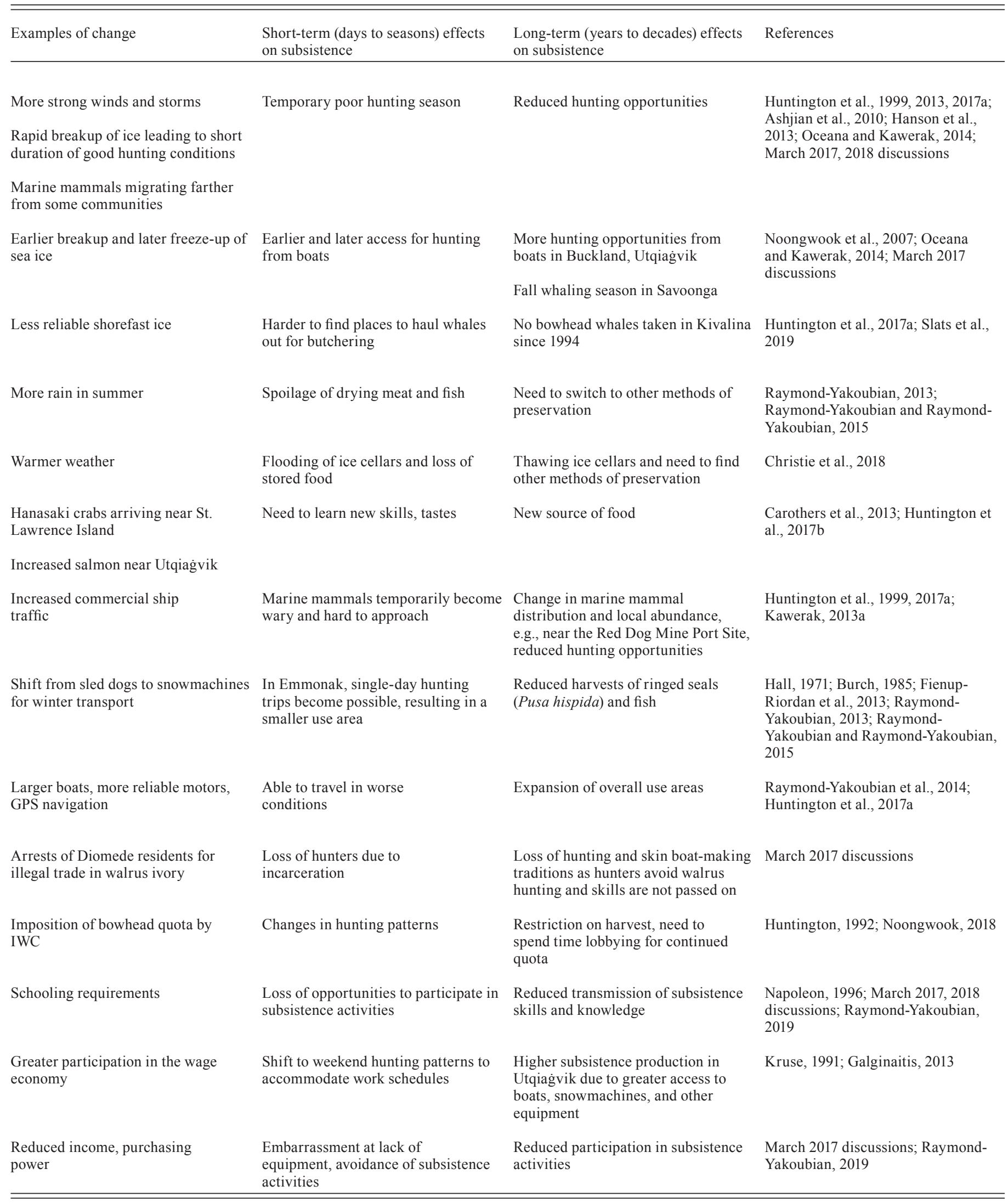


In Table 2, we present examples of several categories of response and potential limits to the effectiveness of a given strategy. Broadly, the strategies fall into two categories: specific actions that can be taken, such as hunting bowhead whales in fall as well as spring, and general approaches that promote problem-solving and innovation, such as persistence and a willingness to experiment.

As noted earlier, the information in both tables was the foundation for our co-analysis discussions. The literature survey also provided an annotated bibliography for the use of Arctic IERP researchers and others interested in Chukchi coastal communities' observations of and experiences with change. This information could be used, for example, to compare findings from research cruises or remote sensing with local observations and understanding. Such efforts are separate from the purpose of this paper.

\section{RESULTS OF THE CO-ANALYSIS}

\section{Types and Effects of Change}

Chukchi coastal communities face many types of change and disturbance, as illustrated in Table 1. Separating these by type (e.g., environmental vs. societal, or local vs. global) is less important than understanding the characteristics of each disturbance. For example, the duration of the disturbance marks the difference between a temporary problem, a seasonal problem, or a long-term problem. The passage of a single ship can disrupt marine mammal behavior for a day or two. The operation of the Red Dog Mine Port Site over many decades has caused a long-term shift in marine mammal distributions in the area. Similarly, a storm can keep hunters on shore for a few days. Poor spring weather or ice conditions can reduce harvests for a season. Declines in the reliability of shorefast ice have contributed to Kivalina not landing a bowhead whale (Balaena mysticetus) since the mid-1990s. Changes in ice breakup patterns have reduced the duration of good seal hunting conditions from weeks to days or even less.

The duration of a disturbance or alteration distinguishes variability from change. The Arctic environment has always been variable, and hunters have had to adjust from day to day, season to season, and year to year. This is considered normal. The annual Pacific walrus (Odobenus rosmarus divergens) harvest on St. Lawrence Island varies greatly due to weather and ice conditions as well as societal factors. The quote in the title of this paper-"We never get stuck" - is indicative of the expectation that community residents will have to find ways to make do, and that attitude is as important as the skill in doing so.

More recently, the environment has also undergone persistent changes. Sea ice forms later and breaks up earlier and more rapidly, affecting marine mammal hunting patterns as well as fishing and crabbing through the ice. The loss of suitable hunting and fishing days has reduced opportunities. On the other hand, earlier breakup can create earlier access, as is the case for Buckland seal hunters, and a late freeze-up has created a new fall bowhead whaling season in Savoonga. More rain in summer makes it harder to dry fish and meat, complicating the task of preserving foods in traditional ways. Ice cellars, dug into permafrost to provide subfreezing storage at no cost, are themselves threatened by thawing permafrost caused by warmer weather and other changes to soil conditions. Stronger and more frequent winds reduce the number of days suitable for boat travel, and larger boats cannot completely overcome this problem.

Shifts in the distribution and abundance of different species have also affected subsistence practices. The increased availability of salmon (Oncorhyncus spp.) in Utqiagivik has created a new fishery and led people there to learn how to smoke salmon. The Hanasaki crab (Paralithodes brevipes) is a relatively new arrival in the waters off Savoonga, providing a new and valued source of food. In both cases, it appears that these changes are likely to persist.

As with environmental variability, short-term societal matters such as family health or a major construction project employing many local residents for a season are typically viewed as normal variability. Of greater note for the communities are long-term changes. Schooling requirements take up considerable time for children, reducing their opportunities to participate in subsistence activities and learn the necessary skills and knowledge. Few schools make allowance for subsistence or provide in-school ways of learning from Elders. Replacing dog teams with snowmachines, which began in the late 1960s, reduced the demand and thus the harvest of seals and fish that were formerly used as dog food. Faster snowmachines have had the counterintuitive effect of reducing the sealhunting area in some communities, because hunters can go out and back in a day rather than making extended camping trips to more distant locations.

The decades-long shift towards greater participation in the wage economy has raised incomes and thus the ability of some people to purchase equipment used for subsistence. Even those without jobs may benefit from relatives willing to share their gear. On the other hand, having a job can reduce the time available for hunting or the flexibility to go when conditions are good. Some employers in the region provide subsistence leave, above and beyond vacation days, but not all work can be put off in this way. The other side of this phenomenon is that people without the means to go hunting or fishing may be left out of subsistence activities. Their situation may be compounded by embarrassment that they have to walk to a harvesting area or use old equipment, so some individuals avoid potential social discomfort by staying home instead of trying to participate in subsistence.

Another persistent shift has been in the regulatory environment. The quota imposed since 1978 by the International Whaling Commission (IWC) for the bowhead whale hunt has, among other things, meant that leaders of the whaling community have had to spend considerable 
TABLE 2. Response categories, examples, and what might constrain the effectiveness of the responses. These examples were documented in the literature included in our project bibliography and supplemented by additional observations shared in our project meetings.

\begin{tabular}{|c|c|c|c|}
\hline Response & Example & Limits on effectiveness & References \\
\hline \multirow[t]{3}{*}{ Using different areas } & Variation in use areas over time & $\begin{array}{l}\text { If species remain available } \\
\text { somewhere in range and the areas are } \\
\text { available for use }\end{array}$ & $\begin{array}{l}\text { Stephen R. Braund \& Associates, } \\
\text { 2010; Gadamus and Raymond- } \\
\text { Yakoubian, 2015a }\end{array}$ \\
\hline & & $\begin{array}{l}\text { Added travel cost if new areas are } \\
\text { farther away }\end{array}$ & \\
\hline & Moving from Diomede to Nome & $\begin{array}{l}\text { If moving is an option, if hunting } \\
\text { remains good in new area, if } \\
\text { newcomers are allowed to hunt there }\end{array}$ & March 2017 discussions \\
\hline Using different times & Fall whaling in Savoonga & $\begin{array}{l}\text { If species remain available and } \\
\text { conditions are suitable }\end{array}$ & Noongwook et al., 2007 \\
\hline Using different species & $\begin{array}{l}\text { Variation in harvest composition from } \\
\text { year to year }\end{array}$ & $\begin{array}{l}\text { If at least some species remain } \\
\text { abundant }\end{array}$ & $\begin{array}{l}\text { Stephen R. Braund \& Associates, } \\
\text { 2010; Fall et al., 2013; Raymond- } \\
\text { Yakoubian, } 2013\end{array}$ \\
\hline \multirow[t]{2}{*}{ Being prepared } & $\begin{array}{l}\text { Continual observation, readiness to } \\
\text { take action when opportunity presents } \\
\text { itself }\end{array}$ & If there are opportunities to seize & $\begin{array}{l}\text { Raymond-Yakoubian et al., 2014; } \\
\text { Kawerak, 2013a, b; Huntington et al., } \\
\text { 2017a; March } 2017 \text { discussions }\end{array}$ \\
\hline & $\begin{array}{l}\text { Use of social media to share } \\
\text { information about animal migrations }\end{array}$ & $\begin{array}{l}\text { Access to social media, presence of } \\
\text { animals }\end{array}$ & Christie et al., 2018 \\
\hline Being persistent & $\begin{array}{l}\text { "We never get stuck"-not giving } \\
\text { up, but continuing to look for ways to } \\
\text { make things work }\end{array}$ & $\begin{array}{l}\text { Until the obstacles are too great to } \\
\text { overcome }\end{array}$ & March 2018 discussions \\
\hline Using new species & Hanasaki crabs in Savoonga & $\begin{array}{l}\text { If there are new species available and } \\
\text { if there are no regulatory barriers }\end{array}$ & Huntington et al., 2017b \\
\hline Using new techniques and tools & $\begin{array}{l}\text { Drones to scout for suitable ice, } \\
\text { marine mammals }\end{array}$ & $\begin{array}{l}\text { If techniques and tools are available } \\
\text { and affordable and if the animals are } \\
\text { still there; regulatory restrictions on } \\
\text { some technologies }\end{array}$ & $\begin{array}{l}\text { Raymond-Yakoubian et al., 2014; } \\
\text { Schwing, 2016; Hughes, 2018; } \\
\text { Woodford, } 2019\end{array}$ \\
\hline Making new use of the harvest & Smoking salmon in Utqiaġvik & $\begin{array}{l}\text { If there are options and the } \\
\text { information needed to employ those } \\
\text { options }\end{array}$ & Kersey, 2011; March 2018 discussions \\
\hline Being willing to experiment & $\begin{array}{l}\text { Hunting the first belugas } \\
\text { (Delphinapeterus leucas) to pass } \\
\text { Point Lay }\end{array}$ & $\begin{array}{l}\text { As long as there are animals available; } \\
\text { tolerance for risk }\end{array}$ & March 2017 discussions \\
\hline
\end{tabular}

time traveling to meetings and other venues to defend their practices, which has taken them away from hunting and other responsibilities in the community. A major enforcement action in the early 1990s against illegal harvests of Pacific walrus tusks led to several hunters from the Bering Strait area being charged with this crime. One result was that the walrus harvest on Little Diomede declined sharply and has not recovered because some prominent hunters were jailed; as a consequence, others were reluctant to hunt. The transmission of skills and knowledge to younger hunters was thus interrupted, creating an even more lasting effect.

\section{Response Strategies}

Environmental changes in the Arctic attract a lot of scientific and media attention. Addressing the root causes of these changes, however, is a challenge. The causes are dispersed globally and include powerful economic interests as well as established patterns of energy-intensive human behavior. Some Arctic activists have advocated for global action on climate change, but it remains a major challenge.

Some societal influences on subsistence, on the other hand, are closer to home or have a clearer focal point. The effects of commercial shipping to Red Dog Mine or the North Slope oil fields can be raised with the companies involved. In the case of North Slope oil activities, a cooperative agreement was reached between whalers and companies to improve communication and reduce or avoid ship traffic that interferes with whaling. Even the IWC quota for bowhead whales is set by a single international body that meets on a regular basis, so whalers know when and where to go to advocate for their way of life. Changing the schedules of local schools and employers has in general proved hard to do, but at least community members have access to the relevant decision makers. Adoption of 
new technology is up to the individual, subject to such considerations as affordability.

Whether the ultimate causes of change can be addressed or not, individual hunters can and do adjust in many ways to respond to change. Communities can pool their talents and resources to do so to an even greater extent. Hunting areas may shift and expand, both because animal distributions change and also because new technologies such as larger boats, more reliable engines, and GPS navigation allow for more efficient and safer travel, though going farther will take more time and fuel. Subsistence activities may also take place at different times, ranging from a shift of a few days or weeks if sea ice breaks up earlier, to Savoonga's creation of a fall whaling season. Harvest composition varies from year to year (e.g., Bacon et al., 2009) and can also shift over time in response to access, species availability, and other factors. Some changes, however, will require more than an individual or community can do alone. Collaboration and cooperation with those outside the community will also be necessary. Such efforts can be as simple as Utqiagivik harvesters learning from friends and relatives farther south how to smoke salmon or as complicated and difficult as persuading the U.S. government and the IWC to permit the harvest of other species of large whales. All of these strategies depend on having animals to harvest at some time and place within reach of the community.

In addition to changing activities, Chukchi coastal residents also recognize the importance of attitudes in creating effective responses to change. These characteristics do not simply exist, but are developed and encouraged within the communities of this study (and undoubtedly far beyond) as distinct skills to be practiced and refined. Harvesters have always been prepared for variable conditions, whether in recognizing signs of danger or being ready to act when opportunities arise. Being ready is not so much a response in itself as the foundation for any other response, from making use of the now-briefer seal-hunting period after shorefast ice breaks up to using social media to share information among communities about animal migrations. Persistence is similarly a necessary virtue, again as illustrated in the adage that "We never get stuck." Using new species, such as the Hanasaki crab, or new tools, such as drones or satellite imagery, for scouting sea ice conditions, or learning new ways to prepare and store foods are all part of a ceaseless search for what will work best at any given time. Here, too, there are ultimately limits to what can be accomplished, but not for lack of trying.

For all the attention to changes in the Chukchi marine ecosystem, widespread changes in subsistence outcomes are hard to identify. There are many relatively modest effects, as shown in the examples in Table 1, but the reduction of seal and fish harvests due to the replacement of dog teams with snowmachines is so far a much larger change than has been forced by environmental change in the region. One reason for the lack of apparent effects is the range of responses used by subsistence harvesters, as shown in the examples in Table 2.
This is not to say that further changes will have similarly modest effects, or that responses will continue to be effective. Coastal residents will remain innovative and committed to providing food for their communities. Modern technology will help in many ways, and remoteness and minimal competition for most of the marine resources of the region leave the coastal communities considerable flexibility in what, when, and where to hunt. On the other hand, increased commercial shipping (AMSA, 2009) and industrial activities such as offshore oil and gas activity (Gautier et al., 2009; Holland-Bartels and Pierce, 2011) create another type of competition, not for species per se but for access to an undisturbed sea, even as they may provide more local income. Those lacking cash or equipment will have less ability to participate in subsistence regardless of the abundance or accessibility of animals and plants. Regulatory restrictions could limit the ability of harvesters to adjust by not allowing the take of animals outside regulatory seasons even though the timing of animal presence or abundance has changed, prohibiting the take of species they have not harvested before, or by preventing them from making up for poor harvests of one species (e.g., bowhead whales) by increasing their take of another (e.g., caribou). Furthermore, the fixed infrastructure of today's communities limits the ability of hunters and fishers to always move to where the fish and animals are abundant or accessible.

Cataloguing the range of factors that influence Chukchi coastal communities and communities elsewhere is in itself of limited value in fostering resilience and adaptation to change. Community well-being will depend on many factors as well as the interplay among those factors, which limits our ability to predict or even to recognize which influences matter most. What is likely more important is the ability of communities to develop their own responses to change on their own terms and with support from and in cooperation with others when necessary and desired. The effects of environmental change on Chukchi coastal communities are not negligible but demonstrable and play out under the influences of societal and other changes that mediate both the effects of those changes and the responses to them.

\section{DISCUSSION}

\section{Co-analysis and Community Perspectives}

The movement towards collaborative research and the co-production of knowledge is in part recognition of the rights of community residents to be more than study subjects (Smith, 1999; Wilson, 2008; Kovach, 2009; Strega and Brown, 2015). Involving Arctic peoples in all phases of a research project is worthwhile on its own merits, recognizing the full intellectual contributions made by everyone involved in such projects and sharing the rewards of credit and income from the work of research. 
Scientifically, it is also reasonable to ask what is gained from a collaborative or co-productive approach as compared with other methods. In our study, the answer lies less in dramatic insights and more in the steady accumulation of additional ideas and perspectives.

The co-analysis emphasizes the importance of the results of change rather than the sources of change, when it comes to their effects on communities and the strategies used to address those changes. Whether marine mammal distribution has shifted because of vessel traffic or reduced sea ice, hunters still have to find ways to adjust. The ability to adjust is useful no matter the cause of change. Addressing the source of the change, by negotiating with a shipping company or advocating for one's community at the IWC, is also a form of adjustment, and doing so can give a sense of agency, which reinforces the idea that one can affect the outcomes that matter. At the same time, changes that stem directly from a specific and identifiable human action, such as industrial activity or an oil spill, are also likely to produce a different reaction among those affected than would an event with unknown or natural causes, such as fluctuation in some animal populations. In the former case, stress is likely to be higher as individuals seek to blame those they see as responsible and realize the problem may have been preventable (e.g., Cunsolo Willox et al., 2013, 2015), whereas in the latter case, people may be better able to get on coping with the change (e.g., Himes-Cornell et al., 2018).

The co-analysis discussions emphasized the importance of attitude (e.g., Walker and Salt, 2012) as well as skill and knowledge, and the crucial role that traditional values and practices continue to play in successful subsistence outcomes. These are not new ideas in the literature on Arctic communities and change (e.g., Hovelsrud and Smit, 2010; Cochran et al., 2013; Ford et al., 2015; Huntington et al., 2017a), but they often receive less attention and emphasis than what is changing. The abilities, both learned and taught, to be ready and to carry on deserve more attention as effective elements of individual as well as collective (i.e., cultural) responses to change and greater recognition as traits essential to the well-being of remote communities in variable, changing, and challenging environments.

Together, these insights suggest a broader scope of inquiry and discussion, not limited to ecosystem studies or societal studies, but taking the community perspective as a starting point to address community needs and concerns (e.g., Huntington et al., 2019). Further documentation of how much is changing and how fast is useful only up to a point. Greater understanding of how people have already adapted to change and how those strategies can be fostered and supported in response to future change is a more useful contribution to supporting the well-being of the region's coastal communities. More important still is a leading role for tribal and community voices and leadership in deciding how they want to shape their own future (RaymondYakoubian and Daniel, 2018). Shared leadership provides an opportunity for true collaboration between scientists and coastal residents and, ultimately, the local, regional, and national policy makers whose decisions will have a large influence on what happens next.

\section{Theories of Change and Response}

From an academic point of view, we can also consider the outcomes of the co-analysis discussions in light of existing theories of change and response, drawing, for example, from ecology and business management. The emphasis on the characteristics of disturbance, especially the role of duration, aligns with the ecological and social-ecological idea of pulse-press dynamics (e.g., Collins et al., 2011; Ratajczak et al., 2017). Pulses are short-term disturbances that cause disruption but from which the system recovers to something close to its original state. Presses are long-term disturbances that lead to long-term alterations in a system's structure and functioning. One poor hunting season may cause hardship and even loss, but communities and cultures have recovered from such events in the past. A change in sea ice conditions, however, may force marine mammal hunters to alter their practices to the point of abandoning previous modes of hunting, as with Kivalina and bowhead whaling, or creating new modes of hunting, as for Savoonga and fall whaling.

Responses to change can be considered technical or adaptive, a concept taken from business management (e.g., Heifetz et al., 2009). Technical changes are those that apply a known solution to a problem, whereas adaptive changes are those that require developing a new solution, typically because the problem is of a nature not previously encountered. Technical changes may often be sufficient for pulse problems, since the basic nature of the system does not change; in a system with high variability, subsistence harvesters have a number of alternatives to use if their primary methods are not sufficient in a given season. Under press-like changes, however, the system itself is likely to change, in turn sometimes, but not always, requiring the development of new knowledge, skills, and methods to achieve similar outcomes. Harvesting the Hanasaki crab may not be a major challenge, but it is still a new skill to learn. The use of new tools such as drones, satellite imagery, and GPS requires experimenting and the generation of new knowledge and skills. On the other hand, being ready to harvest when conditions are right has always been important, even if good conditions for some activities no longer last as long.

When discussing change and response to change, it is important not to overlook what should stay the same (Huntington et al., 2017a), such as being prepared, being persistent, and being willing to experiment (reflected in some entries in Table 2). Sharing remains an essential component of social life in Indigenous communities and their hunting, fishing, and gathering practices (RaymondYakoubian, 2013). Hunters need to be mentally and physically prepared (Kawerak, 2013b). Respect for the animals is critical to the long-term well-being of hunter and 
hunted alike (Kawerak, 2013a; Gadamus and RaymondYakoubian, 2015b; Raymond-Yakoubian and RaymondYakoubian, 2015). Humility and cooperation are necessary for social cohesion. Effective response strategies exist not in isolation, but in a context of healthy interpersonal and human-animal and human-environment relationships (Hovelsrud and Smit, 2010). If that foundation is not solid, then dealing with change may become extremely difficult or impossible, no matter how extensive the available resources. With a solid foundation, by contrast, a great deal can be done even in the face of major environmental change. The ability of Savoonga's whalers to create a fall whaling season in the northern Bering Sea is but one example of what is possible through the synergy of Indigenous skill, knowledge, determination, and collaboration.

Our examples and findings are consistent with other studies of responses to change (e.g., Emery and Flora, 2006; Thornton and Manasfi, 2010; Walker and Salt, 2012), which have shown that humans draw on a wide range of available resources to support an equally wide range of response strategies. Our findings are also broadly consistent with other Arctic studies, which have found that environmental and societal factors both have a large influence on community well-being, including subsistence practices (e.g., Hoveslrud and Smit, 2010; Pearce et al., 2010, 2015; Ford et al., 2015; Rasmussen et al., 2015; Hastrup, 2018; ICC-Alaska, 2015), and that identifying demonstrable changes in community well-being (e.g., population trends) is difficult (Hamilton et al., 2016), perhaps because of the range of responses that provide a buffer against deleterious effects (Huntington et al., 2018).

Understanding the nature of changes, for example as pulse-press dynamics, and the types of responses those changes will require, such as technical and adaptive solutions, can help communities and their allies to focus their efforts and perhaps to make a more persuasive case when needed to convince others to also change. Our co-analysis approach has emphasized the continuing importance of traditional values and practices, such as the attitude of never getting stuck, as well as the need for attention to the conditions within and outside communities that foster effective responses to change. Movement towards approaches that use co-production of knowledge and are highly collaborative is a welcome step in this regard, especially if it can also lead towards collective action.

\section{ACKNOWLEDGEMENTS}

Our research was part of the North Pacific Research Board's (NPRB) Arctic Integrated Ecosystem Research Program. We are grateful to the NPRB for funding and to our colleagues in the Arctic IERP for their ideas and support. We thank the participants in the Chukchi Coastal Communities Project, our fellow team members, who contributed ideas and insights to this paper, including Lucinda Wieler and Niviaaluk Brandt, former project research assistants at Kawerak; Orville Ahkinga, Dora Ahkinga, Opik Ahkinga, and Frances Sistuq Ozenna from Diomede; Raymond Lee Jr. from Buckland; Millie Hawley from Kivalina; Steve Oomituk from Point Hope; Willard Neakok Jr. from Point Lay; and Michael Donovan from Utqiagivik. We also thank the communities and researchers whose work is presented in the publications we reviewed, as well as several colleagues who reviewed portions of this manuscript. Finally, we are grateful to Jeremy Davies for preparing the Figure 1 map and to the reviewers for their constructive comments that led to a much better paper. This paper is Arctic IERP Publication \#39.

\section{REFERENCES}

Alaska Department of Labor and Workforce Development. 2021. 2020 population estimates by borough, census area, and economic region.

https://live.laborstats.alaska.gov/pop/

AMSA (Arctic Marine Shipping Assessment). 2009. Arctic marine shipping assessment 2009 report. Copenhagen: Arctic Council.

https://www.pame.is/images/03_Projects/AMSA/ AMSA_2009_report/AMSA_2009_Report_2nd_print.pdf

Ashjian, C.J., Braund, S.R., Campbell, R.G., George, J.C., Kruse, J., Maslowski, W., Moore, S.E., et al. 2010. Climate variability, oceanography, bowhead whale distribution, and Iñupiat subsistence whaling near Barrow, Alaska. Arctic 63(2):179-194.

https://doi.org/10.14430/arctic973

Bacon, J.J., Hepa, T.R., Brower, H.K., Jr., Pederson, M., Olemaun, T.P., George, J.C., and Corrigan, B.G. 2009. Estimates of subsistence harvest for villages on the North Slope of Alaska, 1994-2003. Barrow, Alaska: North Slope Borough Department of Wildlife Management.

Bartlett, C., Marshall, M., and Marshall, A. 2012. Two-eyed seeing and other lessons learned within a co-learning journey of bringing together Indigenous and mainstream knowledges and ways of knowing. Journal of Environmental Studies and Sciences 2:331-340.

https://doi.org/10.1007/s13412-012-0086-8

Brinkman, T.J., Hansen, W.D., Chapin, F.S., III, Kofinas, G., BurnSilver, S., and Rupp, T.S. 2016. Arctic communities perceive climate impacts on access as a critical challenge to availability of subsistence resources. Climatic Change 139 (3-4):413-427.

https://doi.org/10.1007/s10584-016-1819-6

Burch, E.S., Jr. 1985. Subsistence production in Kivalina, Alaska: A twenty-year perspective. Technical Paper 128. Juneau: Alaska Department of Fish and Game, Division of Subsistence. http://www.adfg.alaska.gov/TechPap/tp128.pdf

Carothers, C., Cotton, S., and Moerlein, K. 2013. Subsistence use and knowledge of salmon in Barrow and Nuiqsut, Alaska. Final Report, March 2013. OCS Study BOEM 2013-0015. Fairbanks: Coastal Marine Institute, School of Fisheries and Ocean Sciences, University of Alaska. 
Christie, K.S., Hollmen, T.E., Huntington, H.P., and Lovvorn, J.R. 2018. Structured decision analysis informed by traditional ecological knowledge as a tool to strengthen subsistence systems in a changing Arctic. Ecology and Society 23(4): 42. https://doi.org/10.5751/ES-10596-230442

Cochran, P., Huntington, O.H., Pungowiyi, C., Tom, S., Chapin, F.S., III, Huntington, H.P., Maynard, N.G., and Trainor, S.F. 2013. Indigenous frameworks for observing and responding to climate change in Alaska. Climatic Change 120(3):557-567. https://doi.org/10.1007/s10584-013-0735-2

Collins, S.L., Carpenter, S.R., Swinton, S.M., Orenstein, D.E., Childers, D.L., Gragson, T.L., Grimm, N.B., et al. 2011. An integrated conceptual framework for long-term socialecological research. Frontiers in Ecology and the Environment $9(6): 351-357$. https://doi.org/10.1890/100068

Cunsolo Willox, A., Harper, S.L., Edge, V.L., Landman, K., Ford, J.D., and the Rigolet Inuit Community Government. 2013. The land enriches the soul: On climatic and environmental change, affect, and emotional health and well-being in Rigolet, Nunatsiavut, Canada. Emotion, Space and Society 6:14-24. https://doi.org/10.1016/j.emospa.2011.08.005

Cunsolo Willox, A., Stephenson, E., Allen, J., Bourque, F., Drossos, A., Elgarøy, S., Kral, M.J., et al. 2015. Examining relationships between climate change and mental health in the circumpolar North. Regional Environmental Change 15:169-182. https://doi.org/10.1007/s10113-014-0630-z

David-Chavez, D.M., and Gavin, M.C. 2018. A global assessment of Indigenous community engagement in climate research. Environmental Research Letters 13(12): 123005. https://doi.org/10.1088/1748-9326/aaf300

Emery, M., and Flora, C. 2006. Spiraling-up: Mapping community transformation with community capitals framework. Community Development 37(1):19-35. https://doi.org/10.1080/15575330609490152

Fall, J.A., Braem, N.M., Brown, C.L., Hutchinson-Scarbrough, L.B., Koster, D.S., and Krieg, T.M. 2013. Continuity and change in subsistence harvests in five Bering Sea communities: Akutan, Emmonak, Savoonga, St. Paul, and Togiak. Deep-Sea Research Part II: Topical Studies in Oceanography 94:274-291. https://doi.org/10.1016/j.dsr2.2013.03.010

Fienup-Riordan, A., Brown, C., and Braem, N.M. 2013. The value of ethnography in times of change: The story of Emmonak. Deep-Sea Research Part II: Topical Studies in Oceanography 94:301-311. https://doi.org/10.1016/j.dsr2.2013.04.005

Ford, J.D., McDowell, G., and Pearce, T. 2015. The adaptation challenge in the Arctic. Nature Climate Change 5:1046-1053. https://doi.org/10.1038/nclimate2723

Gadamus, L. 2013. Linkages between human health and ocean health: A participatory climate change vulnerability assessment for marine mammal harvesters. International Journal of Circumpolar Health 72(1): 20715. https://doi.org/10.3402/ijch.v72i0.20715
Gadamus, L., and Raymond-Yakoubian, J. 2015a. Qualitative participatory mapping of seal and walrus harvest and habitat areas: Documenting Indigenous knowledge, preserving local values, and discouraging map misuse. International Journal of Applied Geospatial Research (IJAGR) 6(1):76-93.

https://doi.org/10.4018/ijagr.2015010105

. 2015b. A Bering Strait Indigenous framework for resource management: Respectful seal and walrus hunting. Arctic Anthropology 52(2):87-101. https://doi.org/10.3368/aa.52.2.87

Galginaitis, M. 2013. Iñupiat fall whaling and climate change: Observations from Cross Island. In: Mueter, F.J., Dickson, D.M.S., Huntington, H.P., Irvine, J.R., Logerwell, E.A., MacLean, S.A., Quakenbush, L.T., and Rosa, C., eds. Responses of Arctic marine ecosystems to climate change. Fairbanks: Alaska Sea Grant, University of Alaska Fairbanks. $181-199$.

https://doi.org/10.4027/ramecc.2013.09

Gautier, D.L., Bird, K.J., Charpentier, R.R., Grantz, A., Houseknecht, D.W., Klett, T.R., Moore, T.E., et al. 2009. Assessment of undiscovered oil and gas in the Arctic. Science 324(5931): 1175 - 1179 .

https://doi.org/10.1126/science.1169467

Grebmeier, J.M., ed. 2014. Pacific marine Arctic regional synthesis (PacMARS) community meetings during February-March 2013. Anchorage, Alaska: North Pacific Research Board.

Hall, E.S., Jr. 1971. The "iron dog" in northern Alaska. Anthropologica 13(1/2):237-254. https://doi.org/10.2307/25604852

Hamilton, L.C., Saito, K., Loring, P.A., Lammers, R.B., and Huntington, H.P. 2016. Climigration? Population and climate change in Arctic Alaska. Population and Environment $38: 115-133$

https://doi.org/10.1007/s11111-016-0259-6

Hansen, W.D., Brinkman, T.J., Leonawicz, M., Chapin, F.S., III, and Kofinas, G.P. 2013. Changing daily wind speeds on Alaska's North Slope: Implications for rural hunting opportunities. Arctic 66(4):448-458. https://doi.org/10.14430/arctic4331

Hastrup, K. 2018. A history of climate change: Inughuit responses to changing ice conditions in North-West Greenland. Climatic Change 151:67-78. https://doi.org/10.1007/s10584-016-1628-y

Heifetz, R.A., Grashow, A., and Linsky, M. 2009. The practice of adaptive leadership: Tools and tactics for changing your organization and the world. Brighton, Massachusetts: Harvard Business Press.

Himes-Cornell, A., Ormond, C., Hoelting, K., Ban, N.C., Koehn, J.Z., Allison, E.H., Larson, E.C., Monson, D.H., Huntington, H.P., and Okey, T.A. 2018. Factors affecting disaster preparedness, response, and recovery using the community capitals framework. Coastal Management 46(5):335-358. https://doi.org/10.1080/08920753.2018.1498709 
Holland-Bartels, L., and Pierce, B., eds. 2011. An evaluation of the science needs to inform decisions on Outer Continental Shelf energy development in the Chukchi and Beaufort Seas, Alaska. Circular 1370. Reston, Virginia: U.S. Geological Survey. https://doi.org/10.3133/cir1370

Hovelsrud, G.K., and Smit, B., eds. 2010. Community adaptation and vulnerability in Arctic regions. London: Springer. https://doi.org/10.1007/978-90-481-9174-1

Hughes, Z. 2018. In doomed Alaska town, hunters turn to drones and caribou as sea ice melts. The Guardian, March 2. https://www.theguardian.com/environment/2018/mar/02/ alaska-climate-change-indigenous-hunting

Huntington, H.P. 1992. Wildlife management and subsistence hunting in Alaska. London: Belhaven Press.

Huntington, H.P., and Eerkes-Medrano, L. 2017. Stakeholder perspectives. In: Adaptation actions for a changing Arctic: Perspectives from the Bering-Chukchi-Beaufort region. Oslo, Norway: Arctic Monitoring and Assessment Programme (AMAP). 11-38.

Huntington, H.P., and the Communities of Buckland, Elim, Koyuk, Point Lay, and Shaktoolik. 1999. Traditional knowledge of the ecology of beluga whales (Delphinapterus leucas) in the eastern Chukchi and northern Bering Seas, Alaska. Arctic 52(1):49-61

https://doi.org/10.14430/arctic909

Huntington, H.P., Noongwook, G., Bond, N.A., Benter, B., Snyder, J.A., and Zhang, J. 2013. The influence of wind and ice on spring walrus hunting success on St. Lawrence Island, Alaska. Deep-Sea Research Part II: Topical Studies in Oceanography 94:312-322.

https://doi.org/10.1016/j.dsr2.2013.03.016

Huntington, H.P., Quakenbush, L.T., and Nelson, M. 2017a. Evaluating the effects of climate change on Indigenous marine mammal hunting in northern and western Alaska using traditional knowledge. Frontiers in Marine Science 4: 319. https://doi.org/10.3389/fmars.2017.00319

Huntington H.P., Begossi, A., Gearheard, S.F., Kersey, B., Loring, P.A., Mustonen, T., Paudel, P.K., Silvano, R.A.M., and Vave, R. 2017b. How small communities respond to environmental change: Patterns from tropical to polar ecosystems. Ecology and Society 22(3): 9.

https://www.ecologyandsociety.org/vol22/iss3/art9/

Huntington, H.P., Loring, P.A., Gannon, G., Gearheard, S.F., Gerlach, S.C., and Hamilton, L.C. 2018. Staying in place during times of change in Arctic Alaska: The implications of attachment, alternatives, and buffering. Regional Environmental Change 18(2):489-499.

https://doi.org/10.1007/s10113-017-1221-6

Huntington, H.P., Carey, M., Apok, C., Forbes, B.C., Fox, S., Holm, L.K., Ivanova, A., Jaypoody, J., Noongwook, G., and Stammler, F. 2019. Climate change in context: Putting people first in the Arctic. Regional Environmental Change 19(4):1217-1223.

https://doi.org/10.1007/s10113-019-01478-8
Huntington, H.P., Danielson, S.L., Wiese, F.K., Baker, M., Boveng, P., Citta, J.J., De Robertis, A., et al. 2020. Evidence suggests potential transformation of the Pacific Arctic ecosystem is underway. Nature Climate Change 10:342-348.

https://doi.org/10.1038/s41558-020-0695-2

ICC-Alaska (Inuit Circumpolar Council-Alaska). 2015. Alaskan Inuit food security conceptual framework: How to assess the Arctic from an Inuit perspective. Technical Report. Anchorage: ICC-Alaska.

https://iccalaska.org/wp-icc/wp-content/uploads/2016/05/ Food-Security-Full-Technical-Report.pdf

Kapsch, M.-L., Eicken, H., and Robards, M., 2010. Sea ice distribution and ice use by Indigenous walrus hunters on St. Lawrence Island, Alaska. In: Krupnik, I., Aporta, C., Gearheard, S., Laidler, G., and Kielsen Holm, L., eds. SIKU: Knowing our ice. Documenting Inuit sea-ice knowledge and use. Dordrecht: Springer. 115-144. https://doi.org/10.1007/978-90-481-8587-0_5

Kawerak. 2013a. Traditions of respect: Traditional knowledge from Kawerak's ice seal and walrus project. Nome, Alaska: Social Science Program, Natural Resources Division, Kawerak, Inc.

- 2013b. Seal \& walrus hunting safety: Traditional knowledge from Kawerak's ice seal and walrus project. Nome, Alaska: Social Science Program, Natural Resources Division, Kawerak, Inc.

Kersey, B. 2011. Enhancing household food security in times of environmental hazards. MSc thesis, University of East Anglia, Norwich, United Kingdom.

Kirby, C.K., Harou, C., Whyte, K.P., Libarkin, J.C., Caldwell, C., and Edler, R. 2019. Ethical collaboration and the need for training: Partnerships between Native American tribes and climate science organisations. Gateways: International Journal of Community Research and Engagement 12(1): 5894.

https://doi.org/10.5130/ijcre.v12i1.5894

Kovach, M. 2009. Indigenous methodologies: Characteristics, conversations, and contexts. Toronto, Ontario: University of Toronto Press.

Kruse, J.A. 1991. Alaska Inupiat subsistence and wage employment patterns: Understanding individual choice. Human Organization 50(4):317-326. https://doi.org/10.17730/humo.50.4.c288gt2641286g71

Lemos, M.C., and Morehouse, B.J. 2005. The co-production of science and policy in integrated climate assessments. Global Environmental Change 15(1):57-68. https://doi.org/10.1016/j.gloenvcha.2004.09.004

Mason, O.K., and Gerlach, S.C. 1995. Chukchi hot spots, paleopolynyas, and caribou crashes: Climatic and ecological dimensions of North Alaska prehistory. Arctic Anthropology 32(1):101-130.

Meadow, A.M., Ferguson, D.B., Guido, Z., Horangic, A., Owen, G., and Wall, T. 2015. Moving toward the deliberate coproduction of climate science knowledge. Weather, Climate, and Society 7(2):179-191.

https://doi.org/10.1175/WCAS-D-14-00050.1 
Moerlein, K.J., and Carothers, C. 2012. Total environment of change: Impacts of climate change and social transitions on subsistence fisheries in northwest Alaska. Ecology and Society 17(1): 10 .

https://doi.org/10.5751/ES-04543-170110

Moore, S.E., Stabeno, P.J., Grebmeier, J.M., and Okkonen, S.R. 2018. The Arctic marine pulses model: Linking annual oceanographic processes to contiguous ecological domains in the Pacific Arctic. Deep-Sea Research Part II: Topical Studies in Oceanography 152:8-21.

https://doi.org/10.1016/j.dsr2.2016.10.011

Napoleon, H. 1996. Yuuyaraq: The way of the human being. Fairbanks: Alaska Native Knowledge Network.

Noongwook, G. 2017. Perspective J: Hunting and co-management. In: Adaptation actions for a changing Arctic: Perspectives from the Bering-Chukchi-Beaufort region. Oslo, Norway: Arctic Monitoring and Assessment Programme (AMAP). 26.

Noongwook, G., the Native Village of Savoonga, the Native Village of Gambell, Huntington, H.P., and George, J.C. 2007. Traditional knowledge of the bowhead whale (Balaena mysticetus) around St. Lawrence Island, Alaska. Arctic 60(1):47-54. https://doi.org/10.14430/arctic264

Oceana and Kawerak. 2014. Bering Strait marine life and subsistence use data synthesis. Juneau and Nome, Alaska: Oceana and Kawerak, Inc.

Pearce, T., Smit, B., Duerden, F., Ford, J.D., Goose, A., and Kataoyak, F. 2010. Inuit vulnerability and adaptive capacity to climate change in Ulukhaktok, Northwest Territories, Canada. Polar Record 46(2):157-177. https://doi.org/10.1017/S0032247409008602

Pearce, T., Ford, J., Cunsolo Willox, A., and Smit, B. 2015. Inuit traditional ecological knowledge (TEK), subsistence hunting and adaptation to climate change in the Canadian Arctic. Arctic 68(2):233-245.

https://doi.org/10.14430/arctic4475

Peltier, C. 2018. An application of two-eyed seeing: Indigenous research methods with participatory action research. International Journal of Qualitative Methods 17(1). 12 p. https://doi.org/10.1177/1609406918812346

Rasmussen, R.O., Hovelsrud, G.K., and Gearheard, S. 2015. Community viability and adaption. In: Larsen, J.N., and Fondahl, G., eds. Arctic human development report II: Regional processes and global linkages. Copenhagen: Nordic Council of Ministers. 427-478.

Ratajczak, Z., D’Odorico, P., Collins, S.L., Bestelmeyer, B.T., Isbell, F.I., and Nippert, J.B. 2017. The interactive effects of press/pulse intensity and duration on regime shifts at multiple scales. Ecological Monographs 87(2):198-218.

https://doi.org/10.1002/ecm.1249
Raymond-Yakoubian, B., and Raymond-Yakoubian, J. 2015. "Always taught not to waste": Traditional knowledge and Norton Sound/Bering Strait salmon populations. 2015 ArcticYukon-Kuskokwim Sustainable Salmon Initiative Project 1333 Final Product. Nome, Alaska: Social Science Program, Natural Resources Division, Kawerak, Inc.

https://kawerak.org/wp-content/uploads/2018/04/TK-ofSalmon-Final-Report.pdf

- 2017. Research processes and Indigenous communities in western Alaska: Workshop report. Nome, Alaska: Social Science Program, Natural Resources Division, Kawerak, Inc. https://kawerak.org/wp-content/uploads/2018/04/ResearchProcesses-and-Indigenous-Communities-in-Western-AlaskaWorkshop-Report.pdf

Raymond-Yakoubian, J. 2013. When the fish come, we go fishing: Local ecological knowledge of non-salmon fish used for subsistence in the Bering Strait region. Final report to the U.S. Fish and Wildlife Service for Study 10-151. Nome, Alaska: Social Science Program, Natural Resources Division, Kawerak, Inc.

__ 2019. Salmon, cosmology, and identity in Elim, Alaska. $\mathrm{PhD}$ thesis, University of Alaska Fairbanks, Fairbanks, Alaska. https://scholarworks.alaska.edu/handle/11122/10531

Raymond-Yakoubian, J., and Daniel, R. 2018. An Indigenous approach to ocean planning and policy in the Bering Strait region of Alaska. Marine Policy 97:101-108.

https://doi.org/10.1016/j.marpol.2018.08.028

Raymond-Yakoubian, J., Khokhlov, Y., and Yarzutkina, A. 2014. Indigenous knowledge and use of Bering Strait region ocean currents. Final report to the National Park Service, Shared Beringian Heritage Program for Cooperative Agreement H99111100026. Nome, Alaska: Social Science Program, Natural Resources Division, Kawerak, Inc.

Schwing, E. 2016. Shishmaref man tracks sea ice conditions with drone. KTOO Public Media, March 14.

https://www.ktoo.org/2016/03/14/shishmaref-man-tracks-seaice-conditions-with-drone/

Slats, R., Oliver, C., Bahnke, R., Bell, H., Miller, A., Pungowiyi, D., Merculief, J., Menadelook, N., Sr., Ivanoff, J., and Oxereok, C. 2019. Voices from the front lines of a changing Bering Sea: An Indigenous perspective for the 2019 Arctic Report Card. In: Richter-Menge, J., Druckenmiller, M.L., and Jeffries, M., eds. Arctic report card 2019. 88-94. Washington, D.C.: National Oceanic and Atmospheric Administration. http://www.arctic.noaa.gov/Report-Card

Smith, L.T. 1999. Decolonizing methodologies: Research and Indigenous peoples. London: Zed Books.

Stephen R. Braund \& Associates. 2010. Subsistence mapping of Nuiqsut, Kaktovik, and Barrow. MMS OCS Study Number 2009-003. Anchorage: U.S. Department of the Interior, Minerals Management Service, Alaska OCS Region, Environmental Studies Program.

Strega, S., and Brown, L., eds. 2015. Research as resistance: Revisiting critical, Indigenous, and anti-oppressive approaches, 2nd ed. Toronto, Ontario: Canadian Scholar's Press. 
Thornton, T.F., and Manasfi, N. 2010. Adaptation—genuine and spurious: Demystifying adaptation processes in relation to climate change. Environment and Society 1:132-155.

https://doi.org/10.3167/ares.2010.010107

Walker, B., and Salt, D. 2012. Resilience practice: Building capacity to absorb disturbance and maintain function. Washington, D.C.: Island Press.

https://doi.org/10.5822/978-1-61091-231-0
Whyte, K. 2017. Indigenous climate change studies: Indigenizing futures, decolonizing the Anthropocene. English Language Notes 55(1-2):153-162.

https://doi.org/10.1215/00138282-55.1-2.153

Wilson, S. 2008. Research is ceremony: Indigenous research methods. Halifax, Nova Scotia: Fernwood Publishing.

Woodford, R. 2019. Drones and hunting. Alaska Fish and Wildlife News, April 2019.

https://www.adfg.alaska.gov/index.cfm?adfg=wildlifenews. view_article\&articles_id $=908$ 